\title{
Being Innovator or 'Imovator': Current Dilemma?
}

\author{
Veronica Scuotto $^{1} \cdot$ Sunil Shukla $^{2}$
}

Received: 25 October 2015 / Accepted: 11 November 2015 /

Published online: 21 December 2015

(C) The Author(s) 2015. This article is published with open access at Springerlink.com

\begin{abstract}
Currently high competitive environment of emerging markets is characterized by a new typology of firm. Such new kind of firm has been defined second mover or 'imovator'. An imovator combines aspects of both imitation and innovation strategies (Shenkar 2010). It exploits the external resources and capabilities of its own network system in order to improve business performance and increase technological capabilities. It takes inspiration from successful innovative products in order to create a similar product but with technical improvements and lower production costs. In the current management literature there are different points of view regards to the competitive advantage to be innovator or imitator: some scholars argue that being innovator is advantageous to companies in order to dominate new market and to acquire a wide range of consumers whereas others point out that it is more efficient and successful to follow the first comer. However none has been studied how the combination between innovation and imitation may affect firms' performance through adpting knowledge exploitation approach and creating relationship with firms' Innovation Network System. So in order to address this gap, the paper analyses two case studies, that is Lenovo from China and redBus.in from India.
\end{abstract}

Keywords Imovator $\cdot$ Innovation $\cdot$ India $\cdot$ China $\cdot$ Emerging markets

\section{Introduction}

The high competitive markets face companies to implement not just an innovation strategy or an imitation one but an imovation strategy, i.e. a combination of both

Veronica Scuotto

veronica.scuotto@uws.ac.uk

Sunil Shukla

sunilshukla@ediindia.org

1 School of Business and Enterprise, University of West of Scotland, Scotland, United Kingdom

2 Development Institute of India and National Team Leader of Global Entrepreneurship Monitor India, Gandhinagar, India 
imitation and innovation strategies (Zhou 2009; Arvanitis \& Seliger 2014). This kind of companies has known as second mover, followers, and 'imovators', among others (Hoppe and Lehmann-Grube 2001; Shenkar 2010). In the current innovation literature, imovator (Shenkar 2010) is term used to classify those companies which "take inspiration from successful innovative products and partly imitates them while offering a product that is different from original, with higher technical specifications and/or lower production costs" (Wang and Scuotto 2012, p.66).

Substantially, such form of companies exploits external knowledge relate to its own network innovation system (NIS) (Freeman 1987), through knowledge exploitation approach which enables them to improve their absorptive capacity. Kim (1997) points out that the knowledge exploitation approach is a process which a firm acquires, absorbs, combines existing knowledge, and transforms it into new knowledge. Hobday (1995) claims that the companies perform a wide range of strategic actions such as design copying, creative adaptation, and technological leapfrogging using exploiting knowledge from external factors. The external factors are identified with government, competitive environment, research and development, investment funds, educational level of human resources, among others (Amara and Landry 2005; Knudsen 2007; Li et al. 2010).

Although several scholars have investigated the difference between innovation and imitation strategies, a little attention has been given to how the combination between innovation and imitation may affect firms' performance through adpting knowledge exploitation approach and creating relationship with firms' Innovation Network System. So in order to address this gap, we intend to analyse two case studies, Lenovo from China and redBus.in from India. These firms are considered valuable examples to observe how the implementation of an imovation strategy may enhance firms' performance. Although Lenovo and redBus operate in two different countries, both are based on knowledge intensive markets (Hung 2009; Altenburg et al. 2008). In these markets, firms develop sophisticated production process adequate for international quality standards and invest more in research and development thanks to the collaboration with the network innovation system (Hung 2009).

The paper has been structured in the following sections: section 2 characteristics of an imovator are described and similarities and differences between between incremental innovation and imovation are argued. Such comparison aims at refining the profile an imovator company. section 3 the relationship between imovator firms and network innovation system in both countries, that is China and India is analysed. Section 4 the methodology has been discussed, in particular how a case study fits the research has been described. Section 5 Lenovo and redBus.in have been looked into in order to show how an imovation strategy performs better that an innovation one. Section 6 discussion and conclusion are presented; in addition to this, managerial and academic implications and research limits are explained.

\section{Imovation Strategy}

In the current innovation and management literature, innovation and imitation strategies have been defined from different prospectives. For instance, Aghion et al. (2005) investigate the relationship between innovation and imitation strategy in reference to 
the competition. A company gets to competitor's market position before racing for the next innovation. Vandenbussche et al. (2006 in Arvanitis and Seliger 2014, p.1) study on innovation strategy with respect to human resources, "showing that skilled labour has a higher growth-enhancing effect closer to the technological frontier under the reasonable assumption that innovation is a relatively more skill-intensive activity than imitation".

Imovation strategy makes products or service more feasible, more cost effective, and much faster. Zhou (2009) and Bessen and Maskin (2009) associate the implementation of the imovation strategy to weak patent protection. The imovator saves not only on $\mathrm{R} \& \mathrm{D}$ process but also on marketing, because customers have already known the novel product or service. It can also "tweak the original to fit shifting consumer tastes or it can leapfrog into the next technological generation" (Shenkar 2010, p.3). The relationship between imitation and innovation becomes complementary and not contradictory.

The notion of imovation is not completely new. It has received attention in literature by analysis of incremental innovation as a form of innovation (Schumpeter 1939). "Incremental innovation enhances and extends the underlying technology so as to reinforce the established technology order" (Tushman and Anderson 1986, p.441). It regards an improvement of an existing product or service that better satisfy the needs of current and potential customers. Incremental innovations refer adaptations, refinements, enhancements, or line extensions of an existing products or services, combining new features with the old ones and offering additional benefits (Varadarajan 2009). Some researchers used to point out those incremental innovations strengthen companies' competitive advantages in the short run but only radical innovations can enable companies strive to remain competitive in long term run (Leifer et al. 2000). Albeit in today intensively competitive market environment, the implementation of incremental innovation is more relevant than radical one because it enables companies to:

"Extending the time horizon of the revenue stream from radical innovation;

Entering new markets in product categories in which the firm currently has a presence;

Achieving and defending product category leadership;

Commanding a higher price relative to the product being supplanted by the incremental innovation, or a price premium relative to competitors' offerings, to achieve higher margins;

Adapting to the structural constraints of the industry ecosystem" (Varadarajan 2009, p.22).

It has measured that over $80 \%$ of the enhancing in a technology arises with an incremental innovation, followed upon the development of a dominant design (Bers and Dismukes 2012).

Along similar lines, an imovation strategy changes the game, leading company's growth. The competitive differentiation advantages of companies may be easily neutralized by competitors' actions and changes in customers' desires. In this backdrop, the imovation strategy plays a relevant role. Imovation is related to innovations by competitors and not solely to past inventions as an incremental innovation. In early stage, such strategy "does not develop a distinctive internal and innovative capability but develop an incremental innovation (Schumpeter 1939) through a process of 
knowledge exploitation of other firms' or other organizations' (e.g. government, research centre etc.) technological capabilities" (Wang and Scuotto 2012, p.67).

So, how does imovation strategy affect firms' performance? What are their main drivers?

Inspiring by these issues, we have designed a model highlighting the drivers of 'imovation' strategy (Fig. 1). It takes into consideration two macro variables, i.e. network innovation system, knowledge exploitation approach, and relative pivotal subdimensions: environmental factors and institutional factors related to innovation network system (NIS) and competence development and skilled human resources allied to knowledge exploitation approach.

Environmental factors as well as institutional ones exert great pressure on companies' innovativeness. Jeong et al. (2006) point out that high competitive environment and technological turbulence as environmental factors facilitate the generation of new products. Li et al. (2010) government and research centres as institutional factors positively impact firms' performance. They also argue that hiring talented employees from foreign firms, companies are able to strength their innovation leadership. Furthermore, knowledge exploitation approach has a critical role in supporting the effective functioning of company's management system (Peng et al. 2008). Imovation strategy guides companies to "gather market, competitor, and technology information and then translate those knowledge resources into learning and strategic actions" (Zhou and Li 2007, p.461) in order to get immediate returns (Schultz 2001; Zack 1999).

\section{A Key Role of Network Innovation System by Enhancing Knowledge Exploitation}

The knowledge exploitation is recognized as one of the major driver of an imovator company due to the growing importance of intangible resources for enhancing companies' competitive advantages (Barney 1991; Collis and Montgomery 1995).

Knowledge exploitation exerts positive externality on companies' productivity. It is defined as "the process through which a firm acquires, absorbs, and combines existing knowledge, and transforms it into new knowledge" (Wang and Scuotto 2012, p.67). This approach exploits knowledge available in their own network system from which companies build a stock of knowledge (Cohen and Levinthal 1990). Many scholars have stressed organizational knowledge and its management as a crucial factor to catch up a market leader in highly competitive market (Dickson 1992; Grant 1996;

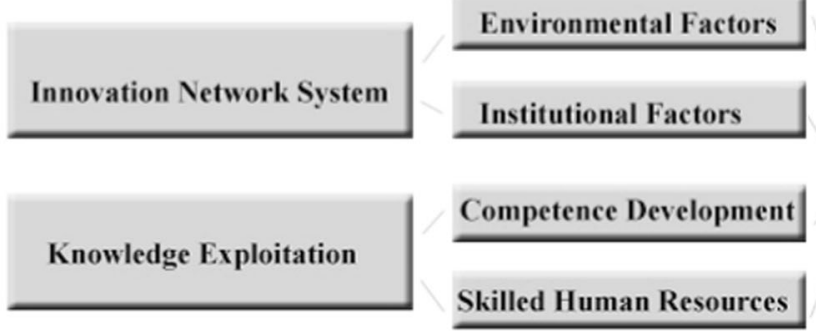

"Imovation" Strategy

Fig. 1 The main drivers of "imovation" strategy 
Hoskisson et al. 2002). Researches of knowledge management and innovation are focused on how knowledge is created, acquired, shared, and diffused into a company (Argyres and Silverman 2004; Hansen et al. 2005; Huff 2000; McFadyen and Cannella 2004; Turner and Makhija 2006). According to the management, literature on 'open innovation', companies draw new products or services on knowledge generated by a wide range of external resources (Chesbrough 2011; Laursen and Salter 2006). Gaining knowledge from external environment, companies are able to deliver superior customer values. "The innovative performance of a country depends to a large extent on how these actors interrelate as elements in a collective system of knowledge creation and use" (Hung 2009 p.30). Freeman (1987) defines this set of relationship as network system of both public and private institutions which activities and interactions initiate, import, modify, and diffuse new knowledge. Such network system determines the innovation performance of national companies (Nelson 1993) through the acquisition of external knowledge and diffusion of new technologies (Metcalfe 1995). Since the strategic recourses are domestic limited and the environment is highly competitive, companies need advanced technologies and marketing expertise to catch up market leader. The imovator companies thus create strategic alliances with international partners in order to achieve economies of scale, to improve technologies, and to enhance their global competitive position (Frost 2001; Wesson 2004).

In the case of China and India, the government, as a part of NIS, establishes strategic alliances with multinational in order to introduce new technologies in the national market. It also invests in R\&D and links the research's system with firms (Lee and Lim 2001; Qiwen 2000). Lu et al. (2008) stress that the effectiveness and efficiency of knowledge exploitation approach is determined by the government. For example, in China, the government supports companies through public funds, Information and Communication Technology investments, a low fiscal burden, creation and diffusion of technological knowledge (Lu et al. 2008). The role of the government in China has related to not just political and economic aspects but cultural ones according to which represents the national family. Not surprisingly, the Department of Public Relation in most firms pays too much attention to the relation with the government (Wang and Scuotto 2012). Since 1990, the government seems to have involved into a strategic role. It aims at supporting and encouraging companies to develop new product/service. As 'go global' strategy was introduced by Chinese government in 1999 in order to improve competitive position of Chinese companies either in domestic market or international ones (Deng 2007). Such strategy supported firms in investing in overseas R\&D centres so as to exploit global advanced technologies and skilled human resources. It also promoted the collaboration between national and corporate innovation systems (Sigurdson 2000). "In emerging countries, the government still plays a salient macrocontrol role in shaping economic activities" (Zhou and Li 2007, p.462).

Another NIS factor is human capital which contributes to beef up the internal R\&D system. In India, there are a high number of technically qualified people which are also proficient in English (Banerjee 2003). Even in China, the growing number of skilled human resources have received training and gotten work experiences either in the USA or other advanced markets (Shulin \& Lundvall 2006). Human capital is flanked by considerable investments in national education system, indeed. Chinese educational system is adopting the 'triple mission' of university introduced by Germany in 1970 (Mroczkowski 2014; Levin 2010). The triple mission regards teaching, research, and 
service to industry. This university model is characterized by close collaboration with business environment as well as with the government to ensure finding for research and development and transform an invention in innovation. Although the improvement of education system and the growing number of skilled people, Chinese companies still invest in importing technologies more than in developing R\&D within their company. Even in India, there is the abundance of low cost labour instead white collar jobs remain rare. Such lack of indigenous skills hinders radical innovation because the more complex of technologies involving tacit knowledge are often embedded in individual or group know-how and organizational structures, and therefore are costly to transfer. For this reason, the government outlined in its economic agenda new projects such as building smart cities, establishing world-class industrial zones, and transforming the country into a manufacturing hub (Schwab 2014).

Strategic alliances also influence positively the creation of new knowledge through the combination of both innovation and imitation strategies. With the relentless technological change, companies require the collaboration with other business or research centres and the creation of a new product becomes a collective effort ( $\mathrm{Su}$ et al. 2008; Zhang and $\mathrm{Li}$ 2008). Chinese and Indian companies face global market through strategic alliances, which are generally subdivided in equity alliances and non-equity alliances. "The equity alliance is a partnership between two or more firms that establish a new company by combining some of their resources and capabilities and owning different percentages of this new company (e.g. joint venture). Differently, non-equity alliance is a form of long-term cooperation where two or more firms share own resources and capability (e.g. R\&D partnership)" (Brondoni 2003; Gnecchi 2009 in Wang and Scuotto 2012, p.68).

In both markets, professional and personal networks build up entrepreneurial and innovation capabilities within companies. Saxenian (2006) investigates two software clusters, i.e. the Indian software cluster in Bangalore and the Chinese computer cluster of Zhongguanun in Beijing. These clusters are characterized by 'the New Argonauts' like technically entrepreneurs, engineers, and scientists who have studied and worked for a long period in the USA. They play a key role in the acquisition, transfer, adaptation, and creation of new product or improvement an existing one. Moreover, the companies embody knowledge through knowledge exploitation approach which leverages the build-up of advanced technologies. "Outsourcing design function has become more common as multinational firms change their attitudes towards homebased R\&D laboratories and decentralize them to co-operate with local laboratories" (Dobson and Safarian 2008, p.303). Many Chinese and Indian companies implement an imovation strategy, acquiring knowledge from foreign competitors and making products and process improvements. In China, the companies also acquire or licence technologies from both foreign firms and research centres (Dobson and Safarian 2008). Even the reforms have led to a decentred innovation system, based on the establishment of horizontal networks with international markets than to local and domestic ones. The relationships are valuable in transforming knowledge, capital, products, and talent (Gilboy 2004).

Bangalore has been defined like the Indian Silicon Valley because a lot hi-tech companies "have set up shops and operate out of state of the art facilities" (Hung 2009, p.36). It was ranked fourth best global hub of technological innovation (Nasscom 2014). 
In a nutshell, the global economy has expanded widely in the last 80 years and has become more complex (Carayannis and Campbell 2011). The market becomes a learning space where the imovator companies may acquire resources through their network system factors. Such factors play a variety of roles towards market support, including risk mitigation and support of remote commerce (Clay et al. 2002), market success (Spicer and Pyle 2002) and legitimisation of new industry entrants (Rao 2002). The companies become competitive not just for their low cost products and services but also for their technology infrastructure. It is well known that companies strive to strengthen their competitive advantage not by invention, but by the clever use of existing processes, products, or technologies (Cooper 1998). This study will employ the case study method so as to draw insights. In reference to the present research, a qualitative approach is apt because Lenovo and redBus.in case studies are theories elaborative in nature, by which we may compare pre-existing theories with practical situations in order to have a clear view of the phenomenon (Eisenhardt 1989). We collected data from multiple sources such as annual report, press releases, and peer review publication from 2000 to 2013. Both companies have been examined by existing theories focus on our main concepts, i.e. global strategies, which includes innovation, imitation, and imovation strategies; knowledge exploitation approach, and network innovation system.

\section{Imovation Strategy via Case-Study Approach}

From the above literature review, we have investigated two of leading Chinese and Indian firms, i.e. Lenovo and redBus.in, as prominent examples of imovator.

These firms have been selected because reflect the main characteristics of an imovator such as:

1. Developed in emerging countries;

2. Belong IT industry;

3. Implementation of successful imovation strategy;

4. Using knowledge exploitation approach;

5. Establishing strong relationship with own network innovation system (Wang and Scuotto 2012; Shenkar 2010; Zhou 2009; Bessen and Maskin 2009). The choice to apply a case study for this research is that this method enables to investigate a 'how' or 'why' question about a contemporary set of events, over which the investigator has little or no control (Johnson, 2008). Moreover, a case study approach has characterized by numerous strengths such as (a) depth of the analysis, (b) high conceptual validity, (c) understanding of context and process, and (d) fostering new hypothesis and new research questions (Yin, 2013). Moreover, Punch (1998) points out that a case study allows a researcher to collect data that are not in the form of numbers and also to analyse deeply routine and problematic firms' s situations (Denzin and Lincoln, 1994; Punch, 1998; Sekaran and Bougie, 2013). Stake (1995) also declares that a case study has been defined as intrinsic, instrumental, collective "robust", and "reliable" method (Baxter and Jack, 2008, p.550). It involves "detailed and holistic investigation (for example, all aspects of a company), using diverse range of measurement techniques. 


\section{Lenovo-Chinese Company}

In China, Lenovo is one of the multinational Chinese companies employed in Hi-tech industry. Liu Chaunzhi, known as the 'Godfather' of China's information technology (IT) industry, founded Lenovo in Beijing in 1984 as the New Technology Development Company (NTD Co.) of the Institute of Computing Technology of the Chinese Academy of Sciences (CAS) (Lu 2000). The support of the government and the research centre positively affected firm's growth, mainly at beginning. It was designated as a 'Guoyou Minying' company, means 'state-owned, people-managed' company, which in such case, the state as well as the owned mother (i.e. CAS) provided start-up capital even if the company had full autonomy in management and personnel decisions. In 1988, Lenovo built up to establish a new headquarter in Hong Kong, where reorganized the company into Legend Computer Group Co. acting as a foreign investor, Legend avoided the regulation PC production by Chinese government. It also became sales and distributive representatives of American and Japanese IT companies in China, acquiring and exploiting both technical and management skills from its foreign partner as HP.

In the early 2000s, the company realized that the increment of international market share related to PC industry would be further objective. Thus, it replaced Legend brand name with Lenovo. The first Lenovo's action was the acquisition of IBM's ThinkPad Pc business, worth $\$ 1.75$ billion. It was a prominent equity strategic alliance, in which Lenovo acquired the 'Think' family group of products, classified as the premium-brand leader in the global PC industry. Such acquisition enabled Lenovo to catch up IBM regards to worldwide distribution, sale networks, and advanced technologies (Deng 2007). Lenovo also brought up IBM's managerial skills increasing technological and innovative abilities by at least 5 years.

The advantages of such the strategic equity alliance were as follows:

To access USA market;

To create efficiencies through economies of scale and scope;

To improve absorptive capacity;

To share the cost of investment such as R\&D;

To implement a co-opt competition (Zhou 2009; Bessen and Maskin 2009).

Most importantly, this deal conveyed incomparable knowledge to Lenovo for developing new product lines like Think-branded commercial PCs and Idea-branded consumer PCs, as well as servers, workstations, and a family of mobile internet devices, including tablets and smartphones. The company explored and acquired new knowledge to keep pace and defend its position in Chinese market as well as to develop a global strategy. The relationship with IBM has compelling evidence that Lenovo improved its R\&D abilities, building a strong R\&D networks in Japan, China, Brazil, and North Carolina, becoming part of global Fortune 500 Company (Lenovo Group Limited 2013/14 Annual Report). It also brought unmatched talent to Lenovo, strengthening its innovation leadership.

Likewise, currently Lenovo is still planning new equity alliances such as the acquisition of IBM's x86 server business as well as Google Inc.'s Motorola Mobility (Bloomberg 2014). These alliances should strengthen channel relationships worldwide, 
and a strong portfolio of intellectual property (IP) and rights. "By combining these strengths with Lenovo's manufacturing efficiency and strong presence in China and emerging markets, this deal will not only create the world's third largest smartphone company, but also the combined capabilities to break through from the pack of Tier 2 players worldwide" (Lenovo Group Limited 2013/14 Annual Report). It has achieved record-high market shares in China, Asia Pacific ("AP"), Americas ("AG”) and Europe-Middle East-Africa ("EMEA") with valuable and strong performance across products and customer segments (Fig. 2).

Building strategic alliances and adopting knowledge exploitation approach have been acknowledged as a couple of the main mode to accelerate Chinese economy growth since 1978 when open-door economic reform was introduced. In fact, Lenovo was able to tactically grasp knowledge and market. The company, currently, "is the largest personal computer (PC) vendor in China and the second-largest in the world, having recently surpassed Dell" (Ahrens and Zhou 2013, p.2). It satisfies consumers' need in more than 160 countries. Aimed at creating sophisticated engineered PCs and mobile internet devices, Lenovo strengthens its brand image through strategic equity alliances and knowledge exploitation.

\section{Lenovo PC Share in 4 GEOs ( $\%$ )}
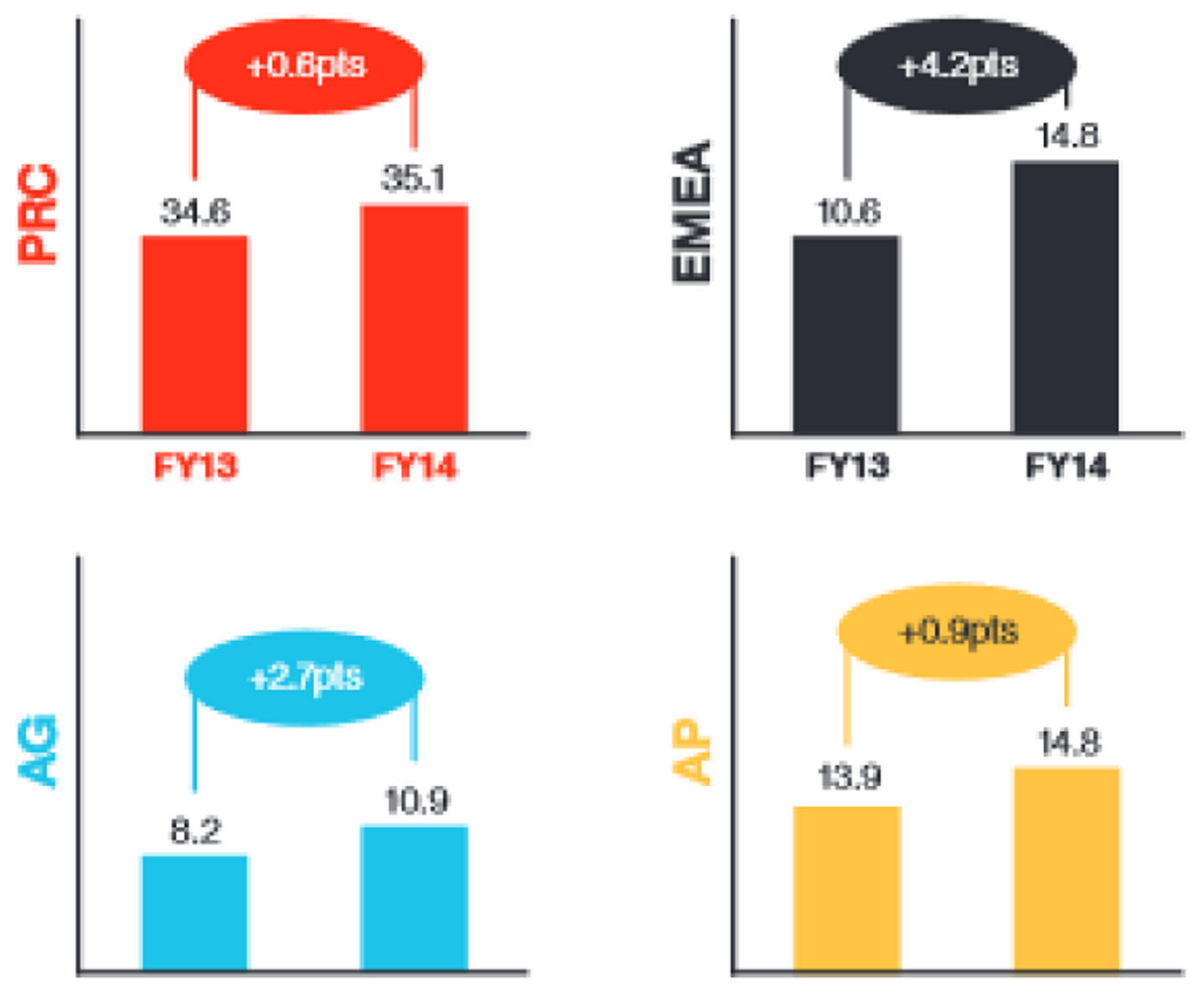

FYP13

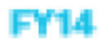

FY13

FY14:

Fig. 2 Lenovo's market share from 2013 to 2014, Source: Lenovo Group Limited 2013/14 Annual Report 


\section{RedBus.in-Indian company}

The emergence of new tourism services and products, coupled with a rapid increase in tourism demand, has driven the wide-scale adoption of IT, particularly, the internet as an electronic intermediary. In other words, the Internet serves as a new communication and distribution channel for suppliers of travel services and products to serve etravellers (Mishra 2013). This new channel also enables tourism businesses to improve their competitiveness and performance. For tourism service suppliers, the Internet provides a platform to sell their products globally to potential travellers round the clock. These suppliers can remotely control their servers to display information on services/products at an electronic speed (Law 2000).

The successful factors for a travel website, from a supplier's perspective, are lower distribution costs, higher revenues, and a larger market share. For travellers, online marketing allows them to communicate directly with tourism suppliers to request information and to purchase products/services at any time and any place (Olmeda and Sheldon 2001). The online ticketing market witnessed a phenomenal growth in the India with $30 \%$ of railway tickets and $40 \%$ of air tickets sold through online channel. Despite an exponential rise in the number of bus ticketing portals in India over the last decade, it is far behind the main stream online ticketing market. With respect to the travel industry, online bus ticketing market estimated to be 5-6 billion and which was around $3-4 \%$ of the overall market had been facing slow growth. The bus travel industry with expected annual turnover of 120 billion and a growth rate of $25 \%$ per year in India was unorganized and highly fragmented.

Within the travel industry, the train and flight ticketing had centralized booking and reservation processes implemented much earlier than bus travel industry. The bus operators were scattered across the country and largely supported by conventional travel agents. There was an absolute need for transparency within the industry so that consumers could avail centralized information system providing details about the total number of bus routes in operation, prices, availability, seat preferences, cancellations, refunds and feedback options (Thomas et al. 2014). This opportunity was sensed by Phanindra Sama, Charan Padmaraju, and Sudhakar Pasupunuri who founded Pilani Soft Labs to provide a web portal known as redBus.in for online bus ticket booking in 2005. Their core objective regards to guarantee a seamless booking and travelling experience for the bus travellers, resolving the information asymmetry between bus operators and bus travellers, indeed. Thanks to their network innovation system composed of university, other businesses and venture capital investors and the knowledge exploitation approach, the three entrepreneurs developed successfully their business.

All three founders were graduates from Birla Institute of Technology and Science and Padmaraju and Sudhakar Pasupunuri had worked at top IT MNCs-IBM, Texas Instruments and Honeywell based both in Bangalaru. In 2006, Phanindra Sama and his friends approached The Indus Entrepreneurs (TiE) to incubate their raw business solution as a venture. They received a great encouragement by their first mentor, Anand Rajaram, successful entrepreneur and seed investor, who led these aspiring entrepreneurs to build one of the most successful ecommerce ventures in the country. With an initial funding of just Rs 2.5 crores from both Seedfund Adivors and Seedfund Helion in 2007 and a subsequent round by Inventus Capital of around Rs 8 crores, the company started growing at a rapid pace from the first year. The first year was not a full 
year and they did Rs 50 lakh worth of business in the first financial year. There were no profits. During the year ending 2008 March, they had turnover was Rs 5 crore. They had 25-30 people working in three offices and had 50 bus operators. In 2009, redBus grew six times and its turnover was Rs 30 crores. In 2010 March, its turnover doubled to Rs 60 crores. Along the support of various VCs, redBus.in faced the highly competitive market and built strong relationships with foreign multinationals. For example, in order to improve its own technology platform, redBus.in exploited Amazon's capabilities to build well engineered and scalable cloud based infrastructure. It also improved the customers' satisfaction through the adaptation of Google BigQuery (i.e. is a web service that lets you do interactive analysis of massive datasets - up to billions of rows). Moreover, creating a solid demand-supply network, the company provided a real-time view of the inventory of available seats and an online and callcentre interface for travellers to estimate and book the bus tickets. It developed three lines of business: first of all, BOSS or the Bus Operators Software System, an ERP platform, that gives bus operators access to their inventory. And then redBus online platform that is a consumer facing travel booking site. The last but not the least, Seat Seller, i.e. a workflow system for travel agents. With BOSS, they charge a subscription fee per month while for Seat Seller they levy a transaction fee. Using redBus online platform, they earn a commission for each ticket booked. The founders always felt that they were more of a travel agent than an e-commerce site.

Likewise, it launched a Virtual Bus Stops for allowing users to see all the bus stops by GPS as well as introduced 'one click payment option' for bus ticketing to make the online transactions quicker and easier. Even if the low Internet penetration and the reluctance in providing the card details for executing the transactions, redBus.in consolidated its position as the leading bus ticket provider by aggregating as many as 1000 bus service operators across 10,000 routes in India. Furthermore, it expanded its network, establishing a strategic partnership with Expedia.

Based on such strategies, redBus.in caught up big Indian players like Yatra and Ticketvala (now makemytrip.com) and made huge entry barrier (Thomas et al. 2014). Over the past few years, redBus.in aggregates 228,000 seats per day, enjoys $70 \%$ market share, sells more than a million tickets a month and has over 600 full-time employees. In one of the biggest deal for the online bus ticket aggregator, it had brought the Karnataka State Road Transport (KSRTC) inventory on to its site in early May this year (Gayathry 2013). It has already tied up with three other state-owned Road Transport Corporations - Rajasthan RTC, Goa RTC and Bihar RTC before that. This transformation in the travel portal business is noticeable with the private bus travel industry growing at a rate of $30 \%$ and estimated to reach $350-400$ billion by 2015 . Today, redBus has around 700 people working in 26 offices across 24 states. This covers all the places where the bus industry is active. They sell more than 5000 tickets every day. They have 1800 bus operators on 67,000 routes. redBus wants to join the Rs. 500 crore club by 2013-2014 (Kapoor and Goyal 2013).

\section{Discussion and Conclusion}

Based on the literature review and the analysis of case studies above, we consider that the high competitive environment (Jeong et al. 2006), the building 
of a stock of intangible asset by knowledge exploitation approach (Peng et al. 2008), and the developing strong relationship within network innovation system (Li et al. 2010) are the key element of a successful imovation strategy. Imovation strategic aspiration in the context of vulnerable strategic position leads Chinese and Indian companies in exploiting knowledge and building strong and valuable relationships, indeed. Imovation strategy guides companies to "gather market, competitor, and technology information and then translate those knowledge resources into learning and strategic actions" (Zhou and Li 2007, p.461) in order to get immediate returns (Schultz 2001; Zack 1999). We also consider appropriate to implement an imovation strategy for creative new products, conversely to Jirjahn \& Kraft (2006) who argue a firm using external knowledge is able to catch up the technological leader but is not able to push technology beyond this frontier.

Looking at, for example, redBus.in, its innovative idea of developing an online bus ticketing platform has empowered bus operators by providing these as an open source platform as well as has made life easy to countrymen (Gayathry 2013). This platform provides ticketing facility on 67,000 routs and ticketing for more than 2 million seats per day. redBus.in focused on offering a unique value to the consumers rather than to succumb under the pressure from competition and thus changed the rules of the game. As redBus.in, Lenovo has introduced innovative products like Think-branded commercial PCs and Idea-branded consumer PCs, as well as servers, workstations, and a family of mobile Internet devices, including tablets and smartphones. Both companies explored and acquired new knowledge to catch up market leader and create a new product or service by their network innovation system (NIS). Lenovo improved its R\&D abilities through the relationship with IBM. It also built a strong R\&D networks in Japan, China, Brazil, and North Carolina, becoming part of global Fortune 500 Company (Lenovo Group Limited 2013/14 Annual Report). This strategic equity alliance brought unmatched talent to Lenovo, strengthening Lenovo's innovation leadership. While redBus.in, along the support of various VCs, faced the highly competitive market and developed valuable relationships with foreign multinationals. For example, in order to improve its technology platform, redBus.in exploited Amazon's capabilities to build well engineered and scalable cloud based infrastructure. Likewise, with the support of the government transports, redBus.in grew at a rate of $30 \%$ and estimated to reach 350-400 billion by 2015 (Thomas et al. 2014).

In line with our model, NIS and knowledge exploitation approach are the main drivers of an imovation strategy in relation to four pivotal subdimensions, i.e. environmental factors and institutional factors allied to innovation network system (NIS) and competence development and skilled human resources linked to knowledge exploitation approach.

Exploiting knowledge and capability of its NIS, redBus.in enabled tourism businesses to improve their competitiveness and performance. As redBus, Lenovo's case study offers a clear view of the relationship among companies' competitive strategy, learning, and capabilities as well as the connection between firms and NIS (Deng 2007). Both case studies demonstrate how the nature and direction of learning grows creating strong relationships with their NIS. As stated by Kim (1997), companies acquire, absorb, combine existing knowledge, and transform it into a new knowledge using the knowledge exploitation approach. Such 
method allows companies to implement various strategic actions such as design copying, creative adaption, and technology leapfrogging (Hobday 1995). The market becomes a learning space where the imovator companies may acquire resources (Carayannis and Campbell 2011) to strengthen their competitive advantage (Cooper 1998). Li et al. (2010) stress that government and research centres as institutional factors positively impact firms' performance. They also argue that hiring talented employees from foreign firms, companies are able to strength their innovation leadership. Such factors play a variety of roles towards market support, including risk mitigation and support of remote commerce (Clay et al. 2002), market success (Spicer and Pyle 2002), and legitimisation of new industry entrants (Rao 2002).

The use of a qualitative approach related to the present research was relevant for comparing pre-existing theories with practical situations in order to have a clear view of "the phenomenon (Eisenhardt et al. 1989). This methodology is apt because Lenovo's and redBus.in case studies are theories elaborative in nature. Both companies have been examined by existing theories focus on our main concepts, i.e. global strategies, which includes innovation, imitation, and imovation strategies; knowledge exploitation, and network innovation system.

However, the framework designed by the analysis of both case studies is not suitable for all imovator companies but it should be a guide to catch up market leader as well as to improve companies' innovation performance through knowledge exploitation and innovation network system. Perhaps, the most important lesson for managers from this research is that by carefully adopting an imovation strategy, companies face big players of advanced market and enhance their business performance as well. Furthermore, this article prompts business academic scholars to extend their analysis from imitation and/or innovation strategy to a combination of both, which would bring significant advantages to companies in emerging markets. In turn, "this may lead to increasingly rapid dissipation of the knowledge stock accumulated by a host's nation firms" (Deng 2007, 80).

The phenomenon analysed inspires further researches focused on not just emerging market but advanced market as well. We suggest studying the imovation strategy towards other point of view as how the big players such as Apple, Samsung, HP, etc. implement an imovation strategy? What are the factors that influence companies' decision making in advanced markets? And then an analysis on the trade-off between advancement and retrenchment would be worthwhile for both emerging market and advanced ones as well.

Open Access This article is distributed under the terms of the Creative Commons Attribution 4.0 International License (http://creativecommons.org/licenses/by/4.0/), which permits unrestricted use, distribution, and reproduction in any medium, provided you give appropriate credit to the original author(s) and the source, provide a link to the Creative Commons license, and indicate if changes were made.

\section{References}

Aghion, P., Howitt, P., \& Mayer-Foulkes, D. (2005). The effect of financial development on convergence: theory and evidence. Quarterly Journal of Economics, 120(1), 173-222. 
Ahrens, N., \& Zhou, Y. (2013). China's competitiveness. Myth, reality, and lessons for the United States, and Japan. Case study: Lenovo. Center for Strategic \& International Studies (CSIS).

Altenburg, T., Schmitz, H., \& Stamm, A. (2008). Breakthrough? China's and India's transition from production to innovation. World Development, 36(2), 325-344.

Amara, N., \& Landry, R. (2005). Sources of information as determinants of novelty of innovation in manufacturing firms: evidence from the 1999 statistics Canada innovation survey. Technovation, 25, 245-259.

Argyres, N., \& Silverman, B. (2004). R\&D, organization structure, and the development of corporate technological knowledge. Strategic Management Journal, 25, 929-958.

Arvanitis, S., \& Seliger, F. (2014). Imitation versus Innovation: What Makes the Difference?. KOF Working Papers, 367. Available at SSRN: http://ssrn.com/abstract=2486572 or http://dx.doi.org/10.2139/ssrn. 2486572.

Banerjee, P. (2003). Resource dependence and core competence: insights from Indian software firms. Technovation, 23(3), 251-263.

Barney, J. B. (1991). Firm resources and sustained competitive advantage. Journal of Management, 17(1), 99120.

Baxter, P. \& Jack, S. (2008). Qualitative case study methodology: Study design and implementation for novice researchers. The Qualitative Report, 13 (4):544-559.

Bers, J. A., \& Dismukes, J., P. (2012). Guerilla innovation - the accelerated radical innovation model meets the real world. International of Innovation and Technology Management, 9(1).

Bessen, J., \& Maskin, E. (2009). Sequential innovation, patents, and imitation. Rand Journal of Economics, 40, 611-635.

Bloomberg, (2014). Lenovo Net Rises 25\% on PC, Smartphone Market Share Gains http:// www.bloomberg.com/news/2014-05-21/lenovo-profit-trails-estimates-as-phone-marketing-costsincrease.html. Accessed 09 September 14.

Brondoni, S., M. (2003) Network Culture, Performance \& Corporate Responsibility, in Wang, D., \& Scuotto, V. (2012). Innovation, second mover, and network system. Symphonya. Emerging Issues in Management (www.unimib.it/symphonya), 2, (pp. 66-76).

Carayannis, E. G., \& Campbell, D., F., J. (2011). Open innovation diplomacy and a 21st century fractal research, education and innovation (FREIE) ecosystem: building on the quadruple and quintuple helix innovation concepts and the "mode 3" knowledge production system. Journal of the Knowledge Economy, 2(3), 327-372.

Chesbrough, H. W. (2011). Open services innovation-rethinking your business to grow and compete in a new era. Boston MA: Harvard Business School.

Clay, K., \& Strauss, R., P. (2002). Institutional Barriers to Electronic Commerce: an Historical Perspective, Ingram P., \& Silverman, B., S. (eds.) Advances in Strategic Management, 19, 247-273.

Cohen, W., \& Levinthal, D. (1990). Absorptive capacity: a new perspective on learning and innovation. Administrative Science Quarterly, 35, 128-152.

Collis, D. J., \& Montgomery, C. (1995). Competing on resources: strategy in the 1990s. Harvard Business Review, 73(4), 118-128.

Cooper, J. R. (1998). A multidimensional approach to the adoption of innovation. Management Decision, 36(8), 493-502.

Deng, P. (2007). Investing for strategic resources and its rationale: the case of outward FDI from Chinese companies. Business Horizons, 50(1), 71-81.

Denzin, N. and Lincoln, Y. (Eds). (1994). Handbook of Qualitative Research: Theories and Issues. Thousand Oaks, CA: Sage.

Dickson, D. C., M. (1992). On the distribution of the surplus prior to ruin. Insurance: Mathematics and Economics, 11(3), 191-207.

Dobson, W., \& Safarian, A. E. (2008). The transition from imitation to innovation: an enquiry into China's evolving institutions and firm capabilities. Journal of Asian Economics, 19(4), 301-311.

Eisenhardt, K. M. (1989). Building theories from case-study research. Academy of Management Review, 14(4), 532-550.

Freeman, C. (1987). Technology policy and economic performance: lessons from Japan. London: Frances Printer Publishers.

Frost, T. S. (2001). The geographic sources of foreign subsidiaries' innovations. Strategic Management Journal, 22(2), 101-123.

Gayathry, S. (2013). Travelling made easy (a case study of redBus.in). Tactful Management Research Journal, 1(11), 1-5.

Gilboy, G. J. (2004). The myth behind China's miracle. Foreign Affairs, 83(4), 33-48. 
Gnecchi, F. (2009) Market-driven management, market space and value proposition, in Wang, D., \& Scuotto, V. (2012). Innovation, second mover, and network system. Symphonya. Emerging Issues in Management (www.unimib.it/symphonya), 2, (pp. 66-76).

Grant, R. M. (1996). Toward a knowledge-based theory of the firm. Strategic Management Journal, 17(S2), 109-122.

Hansen, M., Mors, M., \& Løvås, B. (2005). Knowledge sharing in organizations: multiple networks, multiple phases. Academy of Management Journal, 48, 776-793.

Hobday, M. (1995). Innovation in East Asia: the challenge to Japan. UK: Edward Elgar.

Hoppe, H. C., \& Lehmann-Grube, U. (2001). Second-mover advantages in dynamic quality competition. Journal of Economics \& Management Strategy, 10, 419-433.

Hoskisson, R., Hitt, M., Johnson, R., \& Grossman, W. (2002). Conflicting voices: the effects of institutional ownership heterogeneity and internal governance on corporate innovation strategies. Academy of Management Journal, 45, 697-716.

Huff, A. (2000). Changes in organizational knowledge production. Academy of Management Review, 25, 288293.

Hung, S. W. (2009). Development and innovation in the IT industries of India and China. Technology in Society, 31(1), 29-41.

Jeonga, I., Paeb, H. J., \& Zhouc, D. (2006). Antecedents and consequences of the strategic orientations in new product development: the case of Chinese manufacturers. Industrial Marketing Management, 35(3), 348358.

Johnson, W. H. (2008), Roles, resources and benefits of intermediate organizations supporting triple helix collaborative R\&D: The case of Precarn, Technovation, 28,(4): 495-505.

Jirjahn, U., \& Kraft, K. (2006). Do Spillovers Stimulate Incremental or Drastic Product Innovations? Hypotheses and Evidence from German Establishment Data, ZEW Discussion Papers 06-23, ZEW Zentrum für Europäische Wirtschaftsforschung / Center for European Economic Research.

Kapoor, A., \& Goyal, S. (2013). Business model of service delivery and MSME. Analysis of select cases in India. FICCI - GIZ - SIDBI projection "serving MSME serving India" within the framework of MSME umbrella programme; jointly implemented by GIZ and SIDBI.

Kim, L. (1997). Imitation to innovation. Boston: Harvard Business School Press.

Knudsen, M. P. (2007). The relative importance of interfirm relationships and knowledge transfer for new product development success. The Journal of Product Innovation Management, 24, 117-138.

Laursen, K., \& Salter, A. (2006). Open for innovation: the role of openness in explaining innovation performance among U.K. manufacturing firms. Strategic Management Journal, 27(2), 131-150.

Law, R. (2000). Internet in travel and tourism-part. Journal of Travel \& Tourism Marketing, 9(4), 83-87.

Lee, K., \& Lim, C. (2001). Technological regimes, catching up and leapfrogging: findings from the Korean industries. Research Policy, 30, 459-483.

Leifer, R., McDermott, C. M., O'Connor, G. C., Peters, L. S., Rice, M. P., Veryzer, R. W., et al. (2000). Radical innovation: how mature companies can outsmart upstarts. Harvard Business School Press.

Lenovo Group Limited, 2013/14 Annual Report, the Lenovo Experience. Building a better way.

Levin, R. C. (2010). Top of the class: the rise of Asia's universities. Foreign Affairs, 89(3), 63-75.

Li, J., Chen, D., \& Shapiro, D., M. (2010). Product Innovations in Emerging Economies: the Role

Lu, Q. (2000). China's leap into the information age: innovation and organization in the computer industry. Oxford: Oxford University Press.

Lu, Y., Tsang, E. W., K., \& Peng, M. W. (2008). Knowledge management and innovation strategy in the Asia pacific: toward an institution-based view. Asia Pacific Journal of Management, 25(3), 361-374.

McFadyen, M., \& Cannella, A., Jr. (2004). Social capital and knowledge creation: diminishing returns of the number and strength of exchange relationships. Academy of Management Journal, 47, 735-746.

Metcalfe, S. (1995). The economic foundations of technology policy: Equilibrium and evolutionary perspectives, in Stoneman, P. (ed.), Handbook of the Economics of Innovation and Technological Change, Blackwell Publishers, Oxford (UK)/Cambridge (US).

Mishra, B., R. (2013). Business Standard, 2013. Bangalore, September 26, 2013.

Mroczkowski, T. (2014). From breakthrough to incremental innovation leadership: lessons from Germany. Journal of the Knowledge Economy, 5(2), 409-426.

NASSCOM. (2014). Indian IT BPM industry overview, Available at http://www.nasscom.in/indian-itbpo-industry. Nelson, R. R. (1993). National innovation systems: a comparative analysis. New York: Oxford University Press.

Olmeda, I., \& Sheldon, P. (2001). Data mining techniques and applications for tourism internet. Journal of Travel \& Tourism Marketing, 11(2), 1-20.

Peng, M. W., Wang, D., \& Jiang, Y. (2008). An institution-based view of international business strategy: a focus on emerging economies. Journal of International Business Studies, 39, 920-936. 
Punch, K (1998) Introduction to Social Research: Quantitatie and Qualitative Approaches, London, Sage

Qiwen, L. (2000). China's Leap into the Information Age: Innovation and Organization in the Computer Industry. Oxford University Press, 63-103.

Rao, H. (2002). 'Test Tell': Constitutive legitimacy and consumer acceptance of the automobile: 1895-1912. Ingram Paul, Silverman Brian S. (eds.), Advances in Strategic Management, 19 (pp.307-335).

Saxenian, A. L. (2006). The new argonauts: regional advantage in a global economy. Cambridge, MA: Harvard University Press.

Sekaran, S, U. \& Bougie, R. (2013). Research Methods for Business: A Skill Building Approach. New York. John Wiley \& Sons Inc. 6th Ed.

Schultz, M. (2001). The uncertain relevance of newness: organizational learning and knowledge flows. Academy of Management Journal, 44(4), 661-681.

Schumpeter, J. (1939). Business cycles. New York: Mac Graw-Hill.

Schwab, K. (2014). The global competitiveness report 2013-2014. Geneva, Switzerland: World Economic Forum.

Shenkar, O. (2010). Copycats. How smart companies use imitation to gain a strategic edge. Boston, Massachusetts: Harvard Business Press.

Shulin, G., \& Lundvall, B. (2006). China's innovation system and the move toward harmonious growth and endogenous innovation. Innovation: Management, Policy \& Practice, 8, 1-26.

Sigurdson, J. (2000). Knowledge creation and innovation in geographically dispersed organizations. Asia Pacific Journal of Management, 17, 297-330.

Spicer, A. \& Pyle W. (2002). Institutions and the vicious cycle of distrust in the Russian household deposit market, Ingram Paul, Silverman Brian S. (eds.), Advances in Strategic Management, 19, 373-398.

Stake, R. E. (1995). The Art of Case Study Research. Thousand Oaks, CA: Sage Publications.

Su, Y., Tsang, E. W. K., \& Peng, M. W. (2008). How do internal capabilities and external partnerships affect innovativeness? Working paper. Dallas: University of Texas.

Thomas, S., Pathak, B., \& Vyas, P. (2014). The growth of online bus ticketing industry: redBus route to success in the Indian market. International Journal of Business and Management, 9(11), 247-253.

Turner, K., \& Makhija, M. (2006). The role of organizational control in managing knowledge. Academy of Management Review, 31, 197-217.

Tushman, M. L., \& Anderson, P. (1986). Technological discontinuities and organizational environments. Administrative Science Quarterly, 31(3), 439-465.

Vandenbussche, J., Aghion, P., \& Meghir, C. (2006). Growth, distance to frontier and composition of human capital. Journal of Economic Growth, 11(2), 97-127.

Varadarajan, R. (2009). Fortune at the bottom of the innovation pyramid: the strategic logic of incremental innovations. Business Horizon, 52(1), 21-29.

Wang, D., \& Scuotto, V. (2012). Innovation, second mover, and network system. Symphonya. Emerging Issues in Management (www.unimib.it/symphonya), 2, 66-76.

Wesson, T. J. (2004). Foreign direct investment and competitive advantage. Cheltenham, UK: Edward Elgar Publishing.

Yin, R. K. (2013), Case study research: Design and methods. Newbury Park, CA: Sage Publications.

Zack, H. (1999). Developing a knowledge strategy. California Management Review, 41, 125-145.

Zhang, S., \& Li, X. (2008). Managerial ties, firm resources, and performance of cluster firms. Asia Pacific. Journal of Management, 25, 615-633.

Zhou, W. (2009). Innovation, imitation and competition, the B.E. Journal of Economic Analysis \& Policy, $9(1), 1-14$.

Zhou, Z. K., \& Li, B. C. (2007). How does strategic orientation matter in Chinese firms? Asia Pacific Journal of Management, 24(4), 447-466. 